\title{
Volkslinguïstiek en dialectlexicografie in de zuidelijke Nederlanden ${ }^{1}$
}

\author{
Jacques Van Keymeulen, Vakgroep Nederlandse Taalkunde, Universiteit \\ Gent, België (jacques.vankeymeulen@ugent.be)
}

\begin{abstract}
Samenvatting: De professionele dialectlexicografie voor het zuidelijke Nederlands heeft drie grote regionale dialectwoordenboeken voortgebracht: het Woordenboek van de Brabantse Dialecten (WBD), het Woordenboek van de Limburgse Dialecten (WLD) en het Woordenboek van de Vlaamse Dialecten (WVD). Die drie woordenboeken zijn echter veeleer als thematisch geordende materiaalbasissen voor taalgeografisch onderzoek te beschouwen, dan als echte woordenboeken die op een nauwgezette manier semantische informatie verschaffen over het dialectlexicon. Daarom is de 'dialectrenaissance' in de Nederlanden en Vlaanderen, en de daarmee gepaard gaande lexicografische activiteit van plaatselijke amateurs een verheugend verschijnsel. Zaak is om de tientallen plaatselijke dialectwoordenboeken die de laatste decennia het licht hebben gezien in een efficiënt doorzoekbare database onder te brengen, die een zeer belangrijke aanvulling kan zijn bij de resultaten van de professionele dialectlexicografie.
\end{abstract}

Sleutelwoorden: LEXICOGRAFIE, TAALVARIATIE, AMATEUR, AMATEURLEXICOGRAFIE, DIALECTLEXICOGRAFIE, WOORDENBOEK, WOORDBEELD, REGIONAAL WOORDENBOEK, LOKAAL WOORDENBOEK, DIALECT, TRADITIONEEL DIALECT, VLAAMS, NEDERLANDS, NEDERLAND, BELGIË, METHODOLOGIE, TREFWOORD, GEBRUIKERSGROEP, BRUIKBAARHEID, CORRESPONDENTIEREGELS

\begin{abstract}
Folk Linguistics and Dialect Lexicography in the Southern Netherlands. Professional lexicography for the southern Dutch dialects has produced three major regional dialect dictionaries: the Dictionary of the Brabantic Dialects (WBD), the Dictionary of the Limburgian Dialects (WLD) and the Dictionary of the Flemish Dialects (WVD). The three dictionaries are, however, to be considered rather as thematically arranged collections of dialect words aimed at geographical research than as real dictionaries meticulously providing semantic information on the dialect lexicon. Therefore, the 'dialect renaissance' in the Netherlands and Flanders and the lexicographical activity of local amateurs which accompanies it, is a gratifying phenomenon. It is necessary to incorporate the numerous local dialect dictionaries published during the last decades in an efficient searchable database, which could serve as a very important addition to the results of professional dialect lexicography.
\end{abstract}

Keywords: LEXICOGRAPHY, LANGUAGE VARIATION, AMATEUR, AMATEUR LEXICOGRAPHY, DIALECT LEXICOGRAPHY, DICTIONARY, WRITTEN WORD, REGIONAL DICTIONARY, LOCAL DICTIONARY, DIALECT, TRADITIONAL DIALECT, FLEMISH, DUTCH, THE NETHERLANDS, BELGIUM, METHODOLOGY, HEADWORD, USER GROUP, USEFULNESS, CORRESPONDENCY RULES 


\section{Inleiding}

\subsection{Volkslinguïstiek en dialectlexicografie}

De woordgroepen 'volkse linguïstiek'/'populaire linguïstiek' en de woorden 'volkslinguïstiek' of 'volkslinguïstisch' leveren in Google voor het Nederlands (en Afrikaans) geen of in elk geval geen significante hits op. Tegenwoordig mag dat als bewijs gelden dat de notie in het Nederlandse taalgebied zo goed als onbekend is. 'Folk linguistics' is blijkbaar wel bekend in de Angelsaksische wereld, voor een groot deel dank zij het werk van Preston en Niedzielski. ${ }^{2}$ Met de term wordt het geheel bedoeld van volkse opinies en attitudes tegenover taal; het is de 'populaire taaltheorie'. De metatalige ideeën en percepties die bij het gewone volk leven, worden doorgaans tegenover het wetenschappelijke weten geplaatst en door de wetenschap als 'verkeerd' of in elk geval als onbelangrijk afgedaan. Preston en Niedzielski trachten met hun werk op overigens overtuigende wijze aan te tonen dat onderzoek naar de 'folk theory' nodig is voor een compleet beeld van de 'ethnography of language' en om processen van taalverandering beter te begrijpen. Volkse attitudes tegenover taal dienen door de wetenschap ernstig genomen te worden - ze zijn een valabel onderzoeksobject. 'Volkslinguïstiek' kan m.i. voor de dialectlexicografie op twee manieren belangrijk zijn: allereerst is inzicht in de populaire taalattitudes nodig bij lexicografisch veldwerk; in de tweede plaats zijn een aantal concrete resultaten uit die volkse taalattitudes voortgevloeid, nl. (plaatselijke) woordenboeken.

Een lexicograaf die werkt met mondelinge of schriftelijke enquêtes, zoals voor de verzamelaar van louter oraal overgeleverde taalvariëteiten noodzakelijkerwijs het geval is, moet uiteraard de reacties van de respondenten op zijn vragen kunnen voorzien. Die reacties worden gestuurd door de impliciete taaltheorie en de taalattitudes van de respondenten. In een 'diaglossische' taalsituatie als bijv. die in het huidige Nederlandstalige België (Vlaanderen), waar elke taalvariëteit een plaats heeft op een continuüm tussen traditioneel dialect en Standaardnederlands, wordt een vraag als "Hoe noemt $\mathrm{u} x$ in uw dialect " vandaag de dag niet door iedereen op dezelfde manier opgevat. Wat immers is voor een bepaalde respondent de inhoud van de term 'dialect' in een taalsituatie waarbij de aloude fijnmazige dialectgeografische differentiatie wordt afgelost door taalvariaties die horen bij de nieuwe maatschappij die in de jaren '60 van de vorige eeuw is ontstaan en gekenmerkt wordt door een verhoogde sociale en geografische mobiliteit en een steeds hogere scholingsgraad. In het huidige Nederlandstalige België ${ }^{3}$ bestaan naast elkaar: traditioneel dialect, regiolect, Vlaamse omgangstaal, Belgisch-Nederlands ... een aantal variëteiten zijn daarbij ontstaan onder druk van de nieuwe maatschappelijke omstandigheden en de introductie van de Nederlandse standaardtaal in brede lagen van de bevolking. Is 'dialect' dan voor de respondent de variëteit die zijn grootouders nog konden spreken (maar hij helaas niet meer) of de variëteit die hijzelf praat 
in ongedwongen situaties in de eigen huiskring en door een academicus veeleer als regiolect of Vlaamse omgangstaal opgevat zal worden ... Voelt de respondent zich vervolgens al dan niet gewapend om een dialectvragenlijst in te vullen - de ervaring bij het Woordenboek van de Vlaamse Dialecten leert dat de inhoud van het begrip 'dialect' bij respondent en lexicograaf wel eens ver uit elkaar kan liggen.

In mijn bijdrage zal ik het echter niet hebben over de relevantie van de volkslinguïstiek voor dialectlexicografisch veldwerk, maar wel over de amateurlexicografie, die beschouwd kan worden als het resultaat van populaire noties i.v.m. de oudste taallaag. In wat volgt, zal ik me dus toespitsen op de regionale en lokale dialectwoordenboeken die zijn gemaakt in het zuidelijkNederlandse ${ }^{4}$ dialectgebied, d.i. Nederlandstalig België en de drie zuidelijke provincies van Nederland: Zeeland, Noord-Brabant en Limburg. In dat gebied worden er vier dialectgroepen gesproken: Zeeuws (in Zeeland en op de ZuidHollandse eilanden Goeree en Overflakkee), Vlaams (in Frans-Vlaanderen, West-Vlaanderen, Oost-Vlaanderen en Zeeuws-Vlaanderen), Brabants (in Vlaams-Brabant, Antwerpen en Noord-Brabant) en Limburgs (in Nederlands en Belgisch Limburg). Het is uitdrukkelijk niet de bedoeling een analyse te maken van alle verkeerdheden die in de amateurwoordenboeken aangetroffen kunnen worden - en dat zijn er heel wat - maar wel om hun belang voor de wetenschap voor het voetlicht te brengen.

\subsection{Amateurdialectlexicografie}

Met amateurlexicografie bedoelen we de lexicografie die niet door professionele lexicografen - al dan niet aan een instituut of bedrijf verbonden - wordt beoefend. Men kan de amateurlexicografie voor de Nederlandse dialectologie laten beginnen met het werk van Hoeufft (1836), die een woordenboek voor het dialect van Breda in het licht gaf. De kwaliteit van de amateurwoordenboeken loopt zeer sterk uiteen. De auteur van het momumentale Woordenboek der Zeeuwse Dialecten (WZD), dr. Hendrika C. Ghijsen, was een amateurlexicograaf, maar dan wel een met een doctorstitel, die na vele jaren veldwerk een dialectwoordenboek publiceerde waar voor het eerst alle opgegeven woorden gelokaliseerd werden. ${ }^{5}$ Het WZD wordt daarom beschouwd als het begin van de wetenschappelijke dialectlexicografie in de Nederlanden. ${ }^{6}$ Ook andere academici, zoals Debrabandere (1999), hebben regionale of lokale woordenboeken gepubliceerd, die uiteraard kwalitatief gunstig afsteken tegen de producten van taalkundig ongeschoolden.

Hoewel er goede tot zeer goede dialectwoordenboeken door amateurs zijn gemaakt, is er ook heel wat kaf onder het koren. Heel wat lokale woordenboeken en woordenlijsten worden ontsierd door pijnlijk onjuiste klankinleidingen of door fantastische etymologieën. De inleidingen op de amateurwoordenboeken zijn wel een rijke bron voor een volkslinguïstisch onderzoek naar attitudes tegenover taal en dialect: het is immers daar dat de auteur zijn motivatie aan- 
geeft om met een woordenboek te beginnen en dus zijn taalattitudes blootgeeft. De motivatie is altijd 'idealistisch'; commerciële overwegingen zijn normaal afwezig - wat niet wegneemt dat de meeste lokale woordenboeken bij de lokale bevolking gretig aftrek hebben gevonden.

De handleidingen van Cajot (1995) en van Van Keymeulen (2003) zijn erop gericht om de amateurlexicografie in goede banen te leiden. Van Keymeulen (2003) probeert te dien einde de amateur ervan te doordringen zich te beperken tot datgene wat hij — met enige begeleiding en oefening - wél aankan: het registreren van de woorden van een lokale taalvariëteit en het weergeven van hun belangrijkste betekenissen. Onvolledigheid is daarbij een geringer kwaad dan onjuistheid.

\subsection{Amateurlexicografie voor de zuidelijke dialecten in de 19de en de eer- ste helft van de 20ste eeuw}

Het valt op dat in het zuiden van het Nederlandse taalgebied, meer bepaald in Nederlandstalig België, op het einde van de 19de eeuw/begin 20ste eeuw enkele zeer belangrijke dialectlexicografische werken ontstonden: het Algemeen Vlaamsch Idioticon van Schuermans (1865-1870) beet de spits af. Het Westvlaams Idioticon van De Bo (1873), het Waasch Idioticon van Joos (1900), het Antwerps Idioticon van Cornelissen en Vervliet (1899-1903), het Hagelandsch Idioticon van Tuerlinckx (1886), het Zuid-Oost-Vlaandersch Idioticon van Teirlinck (1908-1924) en nog andere volgden snel. De belangrijkste woordenboeken waren regionaal opgezet, en moesten dus in de trefwoorden abstractie maken van de dialectische fonologie: de trefwoorden zijn noodzakelijkerwijs vernederlandst en vatten dus heel wat fonologische variatie samen.

De grote 19de-eeuwse werken en hun opvolgers in de eerste helft van de 20ste eeuw zijn typische producten van hun tijd. Ze zijn ontstaan vanuit een romantisch gedachtengoed, met een klemtoon op de natuurlijke taal waarin de 'volksziel' verondersteld werd tot uiting te komen en een hang naar een onbezoedeld agrarisch verleden. Bovenal kunnen ze niet los gezien worden van de Vlaamse taalstrijd tegen de Franstalige dominantie - De Bo's woordenboek kadert daarbij in het West-Vlaamse taalparticularisme. De grote dialectwoordenboeken bewezen in elk geval dat de volkstalen een rijke woordenschat hadden; de auteurs ervan hoopten ook dat hun verzamelingen in het Woordenboek der Nederlandsche Taal (WNT), een woordenboek waaraan vanaf 1852 werd gewerkt, terecht zouden komen, een verlangen dat maar gedeeltelijk is bewaarheid. Voor een kort overzicht van deze glorierijke periode van de amateurlexicografie verwijzen we naar Goossens en Van Keymeulen (2006: 74-80).

\subsection{De jaren '70 van de 20ste eeuw en daarna: de dialectrenaissance}

Met 'dialectrenaissance' wordt het verschijnsel bedoeld dat het dialect als voertaal gebruikt wordt voor allerlei (populair-)culturele uitingen: muziek, 
theater, stripverhalen ... Dialect màg weer. Er worden in Nederland zelfs delen van de Bijbel in het dialect vertaald - iets waar niet iedereen even gelukkig mee is. Predikant en burgemeester durven zich in het dialect tot een publiek te richten - ook voor ernstige aangelegenheden. Het verschijnsel dateert van de jaren '70 van de vorige eeuw en is het eerst in Nederland waargenomen. Het Nedersaksisch en het Limburgs zijn er zelfs in geslaagd zich resp. in 1995 en 1997 tot streektalen te laten verklaren met een beroep op (deel II van) het Europees Handvest voor Regionale Talen of Talen van Minderheden. ${ }^{7}$

Het ontstaan van de dialectrenaissance kan zowel in Nederland als in Vlaanderen verklaard worden door een aantal maatschappelijke tendenzen van subjectieve en objectieve aard - die in beide gebieden een ongelijk verloop hebben gekend. Allereerst kan gewezen worden op de stijgende democratisering van de samenleving sedert de jaren ' 60 van de vorige eeuw en daardoor de informalisering van de sociale contacten, waardoor de standaardtaal aan prestige heeft moeten inboeten. Een tweede oorzaak is ongetwijfeld het verdwijnen van de traditionele dialecten, vooral wat de woordenschat betreft. De motivatie voor de oude 19de-eeuwse woordverzamelingen was ook al dat de dialecten verdwenen en dus dringend 'gered' moesten worden; in de jaren '60 van de 20ste eeuw is er in heel Europa echter wel een werkelijk grootschaliger taalverandering op gang gekomen, met het uitwissen van grote delen van de dialectwoordenschat (bijv. nagenoeg de totaliteit van de eeuwenoude landbouwwoordenschat), dan de relatief langzame veranderingen voordien. Een derde oorzaak is ongetwijfeld de zoektocht naar de eigen identiteit en het terugplooien op regionale en lokale eigenheid, die een tegenwicht moet vormen tegen de voortschrijdende Europeanisering en globalisering van de samenleving.

De dialectrenaissance zal de oude dialecten niet doen herleven; dat is ook de bedoeling niet - men zou kunnen volhouden dat de standaardtaal (eventueel met regionale accenten) in Nederland en Vlaanderen zodanig sterk staat dat niemand het gebruik van dialect bij bepaalde gelegenheden of voor bepaalde culturele doeleinden nog als een bedreiging voor de standaardtaal aanvoelt. Het verschijnsel lijkt in Vlaanderen van recentere datum te zijn dan in Nederland, hoewel er in Vlaanderen altijd al een hoogstaande liedcultuur in het dialect is geweest. De liederen die bijv. Wannes Vandevelde vanaf de jaren '60 van de vorige eeuw ten gehore brengt, zijn wel in het Antwerpse dialect, maar zijn van een literair en muzikaal niveau dat de vergelijking met de productie in de Nederlandse cultuurtaal moeiteloos kan doorstaan. Het gebruik van het Antwerps was voor Wannes overigens geen gevolg van een bewuste keuze voor het dialect, maar gewoonweg een evidentie voor een kunstenaar die het Algemeen Nederlands niet goed machtig was.

De verschillen tussen Nederland en Vlaanderen op het gebied van de dialectrenaissance en de attitudes tegenover standaardtaal en dialect zouden het onderwerp kunnen zijn van een boeiende studie. Ik heb het vermoeden dat dan zou blijken dat er geen renaissance is van het dialect zelf, maar enkel van de belangstelling ervoor - een omstandigheid die eigenlijk net aantoont dat het 
oude dialect verdwijnt, wat als een cultureel verlies wordt aangevoeld. Het is echter niet het onderwerp van mijn artikel. In wat volgt, zal ik het hebben over een belangrijk effect van de dialectrenaissance: het maken van lokale woordenboeken.

\section{Het belang van de amateurlexicografie}

\subsection{Aantal en verspreiding}

Op bijgaand kaartje en in de tabel wordt de productie van de lokale dialectwoordenboeken in de zuidelijke Nederlanden gevisualiseerd. We hebben ons gebaseerd op de recente bibliografie van Van Keymeulen e.a. (2007), waarin naast woordenboeken waarschijnlijk ook een beperkt aantal andere lexicografische producten zijn opgenomen. Titels als Het dialect van Beveren en zijn deelgemeenten (Cools 2000) of Waur is d'n tijd naurtoe (Moens 1988) maken het echter niet mogelijk uit te maken of het werk een grammatica, een woordverzameling of nog iets anders bevat. Het zijn overigens beide vrij uitgebreide woordenboeken. Uit de titel van maar een 10-tal werken kon worden opgemaakt dat ze waarschijnlijk uitsluitend verzamelingen uitdrukkingen, spreekwoorden (+ eventueel liedjes, rijmpjes e.d.) bevatten — ze werden in de tabel verwerkt. We waren helaas niet in de gelegenheid om alle werken te bekijken; vele lokale publicaties zijn in eigen beheer uitgegeven voor een plaatselijk publiek en zijn maar moeilijk op te sporen of te verwerven; het gaat daarbij soms om uitgebreide en belangwekkende werken als bijv. het recente Woordenboek van het Schellebels dialect (Van der Eecken 2007), waaraan meer dan 30 jaar is gewerkt en dat meer dan 500 bladzijden dik is. De datum post quem is 1836 met het verschijnen van het werk van Hoeufft.

Bij de interpretatie van de kaart en de cijfers moet met een aantal elementen rekening gehouden worden. Allereerst worden woordenboeken van zeer ongelijke omvang en kwaliteit in de tabel samengenomen: die omvang varieert van een paar tientallen bladzijden met enkele honderden woorden als het Overmeers Woordenboekje (Maes 1994), tot levenswerken als het driedelige Gents Woordenboek van Lievevrouw-Coopman (1952). Voorts is niet steeds heel duidelijk hoe 'plaatselijk' een bepaald woordenboek wel is. De titel (of zelfs de inleiding) op een woordenboek geeft niet steeds voldoende uitsluitsel over het werkelijke geografische bereik van de gepresenteerde woordenschat. Soms is de titel van een woordenboek op geografisch gebied waarschijnlijk té ambitieus, zoals dat van Depraetere e.a. (2007).

Ook de woordenboeken die uitdrukkelijk de bedoeling hebben een hele regio te bestrijken, hebben overigens toch een bepaalde geografische focus. Het Westulaamsch Idioticon van De Bo (1873) bijv. bevat maar weinig kustwoorden, maar is vooral gebaseerd op de zuidoostelijke hoek van West-Vlaanderen niet toevallig de geboortestreek van De Bo (zie Devos 1973). Als een dialect- 
woord in het Westvlaamsch Idioticon staat, betekent dat dus volstrekt niet dat het algemeen West-Vlaams is. Een woordenboek als dat van Rutten (1890), Bijdrage tot een Haspengouwsch Idioticon, bewerkte voornamelijk de gemeente Borgloon. De regionale woordenboeken die in hun titel toch een bepaalde lokaliteit als focus vermelden, zoals Hoeufft (1836) voor Breda of Cornelissen en Vervliet (1899-1903) voor Antwerpen, hebben we in de tabel hieronder opgenomen.

Men moet er ook rekening mee houden dat een plaatsnaam meestal als een administratieve aanduiding opgevat moet worden, die een aantal deelgemeenten met verschillende dialecten kan overkoepelen. Sedert de fusieoperatie voor de Belgische gemeenten in 1977 dekken de meeste gemeentenamen nu andere administratieve realiteiten dan voordien. In het woordenboek van Cools (2000), Het dialect van Beveren en zijn deelgemeenten, wordt dat netjes in de titel aangegeven; dat is echter lang niet altijd het geval.

\begin{tabular}{|l|c|c|c|c|c|c|c|c|}
\hline & West-Vl. & Oost-Vl. & Antw. & Vl.-Br. & Nrd-Br. & Bel.-Lbg & Ned.-Lbg & \\
\hline & B & B & B & B & NL & B & NL & \\
\hline $1830-1840$ & & & & & 1 & & & 1 \\
\hline $1880-1890$ & & & & & & & 1 & 1 \\
\hline $1890-1900$ & & & 1 & & & & & 1 \\
\hline $1900-1910$ & & & & & & & & 0 \\
\hline $1910-1920$ & & & & & & & 2 & 2 \\
\hline $1920-1930$ & & & & & & & 1 & 1 \\
\hline $1930-1940$ & & & & 1 & 1 & & & 2 \\
\hline $1940-1950$ & & & & & & & & 0 \\
\hline $1950-1960$ & & 1 & & & 2 & & 1 & 4 \\
\hline $1960-1970$ & & & & & & & 1 & 1 \\
\hline $1970-1980$ & 1 & 1 & & 1 & 1 & 1 & 4 & 9 \\
\hline $1980-1990$ & 1 & 5 & 1 & 3 & 6 & 6 & 12 & 34 \\
\hline $1990-2000$ & 7 & 10 & 3 & 9 & 16 & 8 & 14 & 67 \\
\hline $2000-2007$ & 7 & 7 & 2 & 3 & 14 & 5 & 16 & 54 \\
\hline & & & & & & & & \\
\hline Totaal & $\mathbf{1 6}$ & $\mathbf{2 4}$ & $\mathbf{7}$ & $\mathbf{1 7}$ & $\mathbf{4 1}$ & $\mathbf{2 0}$ & $\mathbf{5 2}$ & $\mathbf{1 7 7}$ \\
\hline
\end{tabular}

Productie van lokale dialectwoordenboeken in de zuidelijke Nederlanden

Inleidingen op dialectwoordenboeken moeten dus steeds zeer goed nagelezen worden om het geografische bereik van het woordenboek te kennen, in het besef dat heel wat auteurs de neiging hebben in dat verband te overdrijven.

We hebben bij de telling de (soms sterk herwerkte en vermeerderde) herdrukken niet meegerekend, maar hebben het jaartal van het 'eerste initiatief' van de auteur genomen om het woordenboek bij een bepaald decennium in de tabel te plaatsen. Op die manier kwamen we in totaal aan niet minder dan 177 


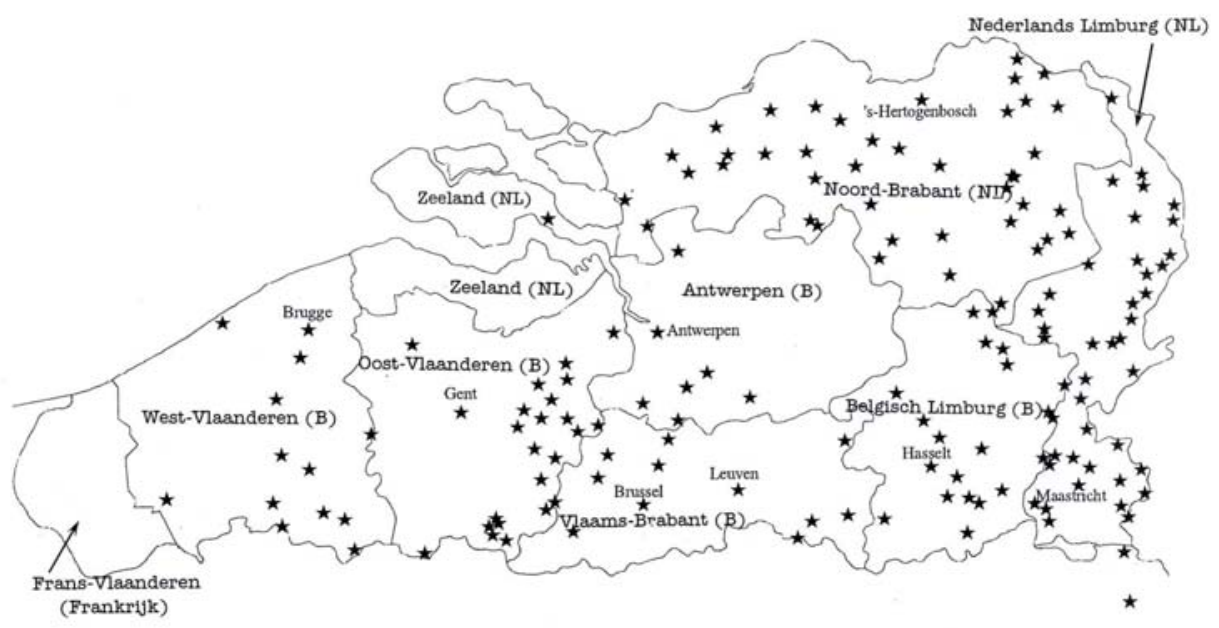

Verspreiding van de lokale woordenboeken in de zuidelijke Nederlanden ${ }^{8}$

'plaatselijke' lexicografische werken die niet aan instituten door professionele lexicografen zijn gemaakt, maar door plaatselijke dialectliefhebbers. De cijfers in de tabel staan voor aantallen woordenboeken, niet voor aantallen gemeenten met een woordenboek. Sommige gemeenten - meestal steden - hebben inderdaad meer dan één woordenboek, waarbij het ene soms op het andere voortbouwt, al dan niet door dezelfde auteur. Voor Maastricht, hoofdstad van Nederlands Limburg, tellen we niet minder dan 7 verschillende lexicografische werken, wat ongetwijfeld te maken heeft met het hoge Limburgse taalbewustzijn (zie ook verder); voor de metropool Brussel, hoofdstad van Vlaanderen, België en Europa, zijn er vier, waaronder het vertalende Marollien-Français/ Français-Marollien ${ }^{9}$ van Starck en Claessens (1988, 19952). Brussel is een geval apart: het aloude inheemse Nederlandse stadsdialect is sedert de 19de eeuw zeer sterk onder de druk van het Frans komen te staan.

Hoewel zowel de kaart als de tabel ongelijksoortig lexicografisch werk samenbrengt - er zijn zowel grote verschillen in kwantiteit (aantal bladzijden!) en kwaliteit als in macro- en microstructureel opzet - vallen toch zowel op chronologisch als op geografisch gebied een paar zaken onmiddellijk op. Op chronologisch vlak is het overduidelijk dat vanaf 1980 het aantal lexicografische initiatieven van plaatselijke amateurs plots toeneemt: bij een vergelijking van de periode 1970-1980 met 1980-1990 zien we een sprong van 9 naar 34 publicaties (in 1960-1970 was er maar één!). Het volgende decennium laat 67 woordenboeken zien. Die opbloei heeft alles te maken met de reeds genoemde dialectrenaissance, die haar wortels heeft in de maatschappelijke veranderingen van de jaren '60 van de vorige eeuw, en die in Nederland blijkbaar krachtiger is geweest dan in Vlaanderen. 
We stellen ons voor dat het in de loop van de jaren '60 voor de bevolking bewust of onbewust duidelijk werd dat de traditionele dialecten onder grote druk kwamen te staan; en in de jaren '70 namen een aantal dialectliefhebbers, meestal leden van plaatselijke culturele verenigingen, dan het initiatief om alleen of samen met anderen dialectwoorden te beginnen te verzamelen, een activiteit die dan in de loop van de jaren ' 80 tot een publicatie leidde. We schatten dat het verzamelen en ordenen van dialectwoordenschat en het publiceren ervan in een dialectwoordenboek van enige omvang als éénmansonderneming in het pre-computertijdperk gemakkelijk een 10-tal jaar in beslag kon nemen. De dialectrenaissance is blijkbaar nog niet ten einde: sedert 2000 tellen we al 54 woordenboeken.

Op geografisch vlak laat de kaart met de verspreiding van de plaatselijke initiatieven allereerst zien dat er voor Frans-Vlaanderen en Zeeland blijkbaar geen plaatselijke dialectlexicografie bestaat. Voor Frans-Vlaanderen heeft die afwezigheid uiteraard te maken met de specifieke taalsituatie van het Nederlandse dialect in Frankrijk; het oude Vlaams is al te ver verdwenen om nog plaatselijke initiatieven te kunnen inspireren en bovendien zijn de personen die zo'n initiatief zouden kunnen nemen in het Frans geschoold, en kunnen geen Nederlands lezen of schrijven. Gelukkig bestaat er sedert 2005 een regionaal Woordenboek van het Frans-Vlaams, door Moeyaert e.a. (2005), een woordenboek waarvoor het materiaal door Belgische Vlamingen is samengebracht. De bijna totale afwezigheid van plaatselijke woordenboeken in Zeeland heeft dan weer een andere oorzaak; de omvang, kwaliteit en bekendheid van het Woordenboek der Zeeuwse Dialecten (+ het Supplement erop) - een werk dat voor het Zeeuws als het ware symbool staat - zijn zodanig hoog dat geen enkel individu de noodzaak heeft gevoeld om daarnaast nog met een lokaal woordenboek te beginnen. Alle dialectgeografische activiteit van de talrijke Zeeuwse vrijwilligers werd decennialang naar hetzelfde product toegeleid doordat alle dialectliefhebbers van de provincie via de Zeeuwsche Vereeniging voor Dialectonderzoek werden ingeschakeld bij de materiaalverzameling. Wel zijn er op initiatief van mevr. E.J. Van de Broeke-de Man negen zgn. regioboeken verschenen, monografieën van de verschillende Zeeuwse eilanden en gebiedsdelen, waarin aanvullingen op het WZD in een thematische ordening werden gepresenteerd in de vorm van verhalen en gedichten over de geschiedenis van het betrokken gebied. Alle nieuwe woordenschat uit die regioboeken kwam achteraf in het Supplement op het WZD terecht.

De concentratie van tekentjes op de kaart is hoger in de Nederlandse provincies (behalve dus Zeeland) dan in de Belgische. Nederlands-Limburg neemt het voortouw met 52 woordenboeken; Noord-Brabant volgt met 41 publicaties; dan komen de Belgische provincies met 20 voor Belgisch Limburg, 24 voor Oost-Vlaanderen, 17 voor Vlaams-Brabant, 16 voor West-Vlaanderen en 7 werken voor de provincie Antwerpen. Hoewel we in het licht van bovenvermelde beperkingen m.b.t. de tabel voorzichtig moeten zijn, komt er toch een patroon naar voren. Het lijkt duidelijk dat de amateurdialectlexicografie in Nederlands- 
talig België later op gang komt en tot vandaag minder krachtig is dan in Nederland. Voor nagenoeg elk decennium scoren de twee Nederlandse provincies beter dan de vijf Belgische (één keer, in 1980-1990 scoren Noord-Brabant en Belgisch Limburg gelijk). ${ }^{10}$ Dat kan verklaard worden door het feit dat de traditionele dialecten in Vlaanderen langer bleven doorleven dan in Nederland, waardoor de amateurlexicografen later gemotiveerd werden om een dialectwoordenboek te schrijven. Ook is het zo dat bij de massale invoering in de jaren '60 van de Nederlandse standaardtaal in de Vlaamse scholen via de zgn. ABN-campagnes, ${ }^{11}$ de strijd voor het Algemeen Nederlands meestal verward werd met een strijd tegen de dialecten. De dialecten werden gestigmatiseerd als minderwaardige taalvariëteiten, die geen ernstige aandacht waard waren. Tegenwoordig heeft men zowel in Vlaanderen als in Nederland tegenover de dialectische (en andere) taalvariëteiten een meer ontspannen en tolerantere houding.

De concentratie aan woordenboeken in de Limburgse provincie van beide landen is opvallend: samen 72 lexicografische producten. Die drukke bedrijvigheid is ongetwijfeld te verklaren door het regionale taalbewustzijn van de Limburgers - ook over de staatsgrens heen — dat zich ook vertaalt in een goed georganiseerd verenigingsleven op dialectgebied en de erkenning van het Limburgs als 'streektaal' (althans in Nederland, niet in België). In de andere provincies van Nederlandstalig België kunnen we geen klaar geografisch patroon zien. Er blijkt een concentratie te zijn in het oosten van Oost-Vlaanderen, die misschien te maken heeft met een relatief hoog dialectbewustzijn: het Vlaamse dialectgebied (Frans-, West- en westelijke 2/3 van Oost-Vlaanderen) en het Brabantse (Vlaams-Brabant, Antwerpen, Noord-Brabant) raken daar elkaar en vormen een isoglossenbundel die een aantal markante taalverschijnselen bevat. De relatief sterke dialectische differentiatie in dat gebied heeft misschien meegebracht dat de gemiddelde aandacht voor taal bij de bevolking hoger is dan elders. Op andere plaatsen is het voorkomen van een plaatselijk woordenboek waarschijnlijk gewoon te danken aan de toevallige motivatie van een dialectliefhebber of een culturele vereniging. Er zijn meer woordenboeken voor grote dan voor kleine gemeenten (al zijn er uitzonderingen), wat uiteraard te maken heeft met de grotere bevolking en met de aanwezigheid van (sterkere) culturele verenigingen die een lokaal lexicografisch initiatief kunnen nemen.

Het bestaan van een ouder regionaal dialectwoordenboek blijkt het plaatselijke enthousiasme niet te kunnen temperen. De grote 19de-eeuwse woordenboeken voor bijv. West-Vlaanderen (De Bo 1873) of het Waasland (= noordoostelijk Oost-Vlaanderen) (Joos 1900) waren zeer uitgebreid en - de tijd waarin ze ontstaan zijn in acht genomen — van uitstekende kwaliteit. Ze werden overigens op het einde van de 20ste eeuw herdrukt (ook een teken van dialectrenaissance!) en waren dus opnieuw beschikbaar. Toch ontstonden net in het Waasland de uitvoerige en kwaliteitsvolle woordenboeken van Pieters (1995) voor de stad Lokeren en Cools (2000) voor Beveren. Beide auteurs zijn 
overigens op de gelukkige gedachte gekomen om de hulp van de universiteit in te roepen bij hun onderneming. In hetzelfde dialectgebied kreeg ook het dorp Belsele (nu deelgemeente van de stad St.-Niklaas) zijn woordenboek met De Belie 2006). Het Waasch Idioticon van Joos heeft blijkbaar veeleer stimulerend dan remmend gewerkt op de plaatselijke amateur.

\subsection{Macro- en microstructuur in de amateurwoordenboeken}

\subsubsection{Macrostructuur}

De macrostructuur van een plaatselijk dialectwoordenboek wordt in eerste instantie bepaald door de motivatie en taalattitude van de amateurlexicograaf, meer dan door de gebruikersbehoeften. Die motivatie is - al dan niet uitdrukkelijk in de inleiding van het woordenboek meegedeeld - in alle gevallen het vastleggen voor het nageslacht van de met verdwijnen bedreigde dialectwoordenschat, die veelal als typisch voor de plaatselijke gemeenschap wordt beschouwd. Uit heel wat inleidingen blijkt dat de auteur de teloorgang van het dialect betreurt, die evolutie wel onvermijdelijk vindt, maar toch een poging wil ondernemen om tenminste een deel van de taalidentiteit van de lokale gemeenschap te redden. Alle lokale woordenboeken zijn dan ook in principe contrastief opgezet; ${ }^{12}$ woorden die enkel fonologisch van het Algemeen Nederlands verschillen, krijgen normaal geen aandacht, tenzij ze dialectische betekenissen dragen. Veel amateurs zijn erg op zoek naar wat 'typisch' is voor het eigen dialect, en zullen dan ook curiosa of erg oude dialectwoorden koesteren.

Nagenoeg alle amateurwoordenboeken zijn alfabetisch geordend. Er zijn erg weinig uitzonderingen: maar een paar titels duiden op een andere aanpak, als het Thematisch Woordenboek van het Tungelroys (Kooijman 1985) of het woordenboek voor Reusel van Van Gompel (2002-2006), dat in verschillende delen is opgedeeld: De mens, de wereld, enz. ... Wel is het zo dat een aantal werken verhalen bevat waarbij de dialectwoordenschat omtrent een bepaald onderwerp wordt aangebracht door een volkscultureel onderwerp (bijv. streekgerechten) te beschrijven. Dat is bijv. de werkwijze van de Zeeuwse regioboeken. De alfabetische ordening wordt ongetwijfeld als vanzelfsprekend ervaren doordat de meeste auteurs enkel met dat type woordenboeken vertrouwd zijn, hoewel de doelstelling die uit heel wat inleidingen spreekt - een beeld schetsen van het leven van vroeger - een thematische ordening aannemelijker maakt. Ik denk dat een plaatselijk dialectwoordenboek, een werk dat steevast gretig aftrek vindt bij de lokale bevolking, slechts zelden als naslagwerk gebruikt wordt, maar veeleer als een boek waarin gegrasduind wordt op zoek naar mooie, oude woorden of pittige uitdrukkingen.

De macrostructuur van een amateurwoordenboek kan nog heel wat meer bevatten dan alleen maar woorden. Vele auteurs zijn bijv. tegelijk ook amateurhistorici of hebben ook andere culturele belangstellingen, die ze in hun 
woordenboek op een of andere manier kwijt proberen te raken. Een aantal woordenboeken bevat bijv. familienamen, bijnamen, rijmpjes en kinderliedjes ... die eventueel in appendices worden ondergebracht, samen met lijsten van Franse leenwoorden, scheldwoorden en vloeken, spreekwoorden en zegswijzen. Sommige auteurs kunnen daarbij maar moeilijk maat houden.

Wat de macrostructuur van de amateurwoordenboeken van na de jaren ' 80 van de vorige eeuw betreft, kunnen we samenvattend stellen dat vanuit een conserverende motivatie en de vertrouwdheid met alfabetische standaardtaalwoordenboeken, het allergrootste deel van de amateurlexicografie de klemtoon legt op het constrastieve deel van de woordenschat van de oudste taallaag in het dialect, in een alfabetische volgorde.

\subsubsection{De microstructuur}

De microstructuur van de meer dan 177 woordenboeken in de bibliografie van Van Keymeulen e.a. (2007) loopt uiteraard zeer uiteen, naargelang van de opzet/omvang van het woordenboek en de (taalkundige) scholingsgraad van de auteur. Nagenoeg alle woordenboeken bevatten dialectische trefwoorden en betekenisomschrijvingen met het Standaardnederlands als metataal; ze kunnen dus beschouwd worden als vertaalwoordenboeken dialect $\rightarrow$ Algemeen Nederlands. ${ }^{13}$ De meeste plaatselijke woordenboeken proberen ook de dialectische uitspraak op een of andere manier in de microstructuur weer te geven. ${ }^{14}$ In wat volgt, beperk ik mij tot de vorming van de trefwoorden en de manier waarop de dialectische uitspraak wordt weergegeven.

Er zijn in principe twee manieren om dialectische trefwoorden te vormen in een alfabetisch geordend woordenboek: de eerste manier is een dialectspelling te ontwerpen en de trefwoorden in die spelling neer te schrijven; de tweede manier is de standaardtaal als referentie te gebruiken en de dialectwoorden te 'vernederlandsen'. Met 'vernederlandsen' wordt bedoeld dat de fonemen van het dialectwoord worden vervangen door hun AN-pendant en vervolgens volgens de Nederlandse spellingregels worden neergeschreven. De dialectuitspraak kan dan na het trefwoord toegevoegd worden, in IPA of op een andere manier. Een dergelijke werkwijze werkt uiteraard het best als het dialectwoord in het AN een lexicale pendant heeft (eventueel met een andere

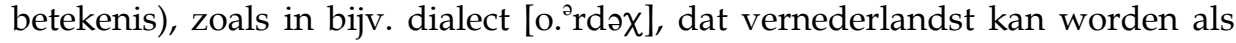
$<$ aardig >. In de meeste zuidelijke dialecten betekent het woord aardig 'eigenaardig'; in het AN echter 'lief'. Die werkwijze blijkt echter ook te werken voor het formeel-contrastieve deel van de dialectwoordenschat. We gaan er immers vanuit dat de dialectsprekers, die heden ten dage alle het $A N$ tenminste passief beheersen, hun dialectwoorden intuïtief kunnen vernederlandsen. In elk geval blijken de respondenten tot op grote hoogte in staat woorden die wel in hun dialect, maar niet in het AN voorkomen, 'op z'n Nederlands' neer te schrijven. Met de vernederlandste dialectwoorden worden als het ware de intuïtieve 'woordbeelden' gevat die bij een dialectspreker aanwezig zijn. Die 'woordbeel- 
rang zn. v.; mv. -en; dim. -sken: rij. (school) In de rang staan in de rij staan. Een gieël rang schoolkadéjjen. [rang].

rank zn. m.; mv. -en: dim. -sken: 1. hopperank. Zoe lank a(l)s nen hoeprank. (uitdr) Van de rank krâigen slaag krijgen. (uitdr.) Hè és de rank ni wêd veu(r) zèn âigen op t'hangen. 2. (mv.) slimme streek, list. (uitdr.) Ranken in zèn voor hémmen vol (heimelijke) streken zitten; (var.) ranken in zèn lâif hémmen; (var.) ranken inhémmen.

z. rank.

ranseln regelm. ww.; ranseldn, geranseld: eventjes ter sprake brengen vooral om er meer over te weten; over iets in het voorbijgaan reppen. Ranselt daa(r) neki $n a a(r)$. ' $k$ Hém der neki van geranseld maa(r) hè zâ niks. [ranselen; verw. met randen, ranten (praten)].

ransènjeern regelm. wederk. ww.; ransènjeedn, geransènjeed: inlichtingen inwinnen. ' $k$ Gon ma neki ransènjeern. [renseigner (Fr.)].

rap (1) bn.: 1. vlug. (uitdr.) Zoe rap a(l)s de blôrn dat wôn zo vlug als de blaren die waaien; (var.) zoe rap a(l)s téln!; (var.) zoe rap a(l)s iet. 2. slim, schrander. Ne rappen. [rap]

rap (2) zn. v.; mv. -pen; dim. -peken: roof, korst. Dê van As goenken naa(r) Blaazerus veu( $r$ ) teegen de rappen (KP). [rap].

rapiet bn.: vlug. (zgw.) Sâs rapiet gezegd van eten waaraan bij gebrek aan tijd onvoldoende zorg was besteed. Ne rapietn, een rapiete een vluggerd. [rapide (Fr.)].

rappebloem $\mathrm{zn}$. altijd mv.: (Mazenzele) volksnaam voor bosanemoon die de volkswijsheid kwalijke eigenschappen toeschreef; wie de anemoon aanraakte zou rappen (korsten van wonden) op de ogen krijgen. [rap(pe) + bloem]

rappeken $\mathrm{zn}$. o.: (gez.) Op een rappeken gezegd van snel cafébezoek. [rappeken].

rappeleern regelm. ww.; rappeleedn, gerappeleed: 1 . herinneren. $A(l) s$ ik het vergeet, goint ma rappeleern? zul je er mij aan herinneren als ik het vergeet? 2. (wederk.) Ik rappeleer ma daa( $r$ ) niks van! ik herinner er mij niets van. [rappeler (Fr.)].

rapte zn. v.: gauwte. (samenspr.) A. Gommen ieëne pakken? B. Allêi, in de rapte! [rapte].

râr zn. m.: mv. -s: mannetjeskonijn. (samenspr.) A. 't És verniet! B. Verniet? (spr.) Verniet gon de katn naa(r) de râr! (uitdr.) Ne goeje râr mag ni vait staan! [rijder; FFP 25.2.2].

ras $\mathrm{zn}$. o.: een vies ras gemeen volk. [ras].

rậschittink zn. v.; mv. -gen: (boogschutter) rouwschieting ter ere van overleden lid. [FFP 22].

rastieël zn. o.: ruif voor paarden. [rasteel; Ofr. rastelier].

z. hoeë.

rat zn. v.; alleen als dim. -teken: 1. snel, bijdehands kind. 2. (kleine) bijverdienste. Hè gaat hie $(r)$ èn daa( $r)$ nog een ratteken doên gezegd van gepensioneerde die ergens nog wat gaat bijverdienen. 3. (dim.) koosnaam voor meisje. [ratteken].

ratatoeil $\mathrm{zn} . \mathrm{m} .:$ 1. etensresten die bij mekaar geklutst zijn. 2. minderwaardig volk, plebs. [ratatouille (Fr.); FFP 8].

rateern regelm. w.; rateedn, gerateed: missen. 'k Hém main tram gerateed! Wâiln hémmen makannere gerateed! Dat gewêir

Trefwoorden in een dialectspelling uit het Woordenboek van het Asses (Pletinckx 2003: 517) 
ze de mèlk u:t euren ieëmer deur 'n mèlkzei in de mèlkkiet. - Synoniemen: melkzeef [mèlkzeef] en melkzift [mèlkzift].

Niet in KA, ME; in KI: [mèlkzè:].

Melsele [Meiëlsen]: Melsele, een der acht deelgemeenten van Beveren. Ik zin $i$ Meiëlse gebooren, èn ik voel mi noch âlt wa ne Meiëlseneiër, è pertâng ik wieën der al guuël lâ:nk nemieër... Moaër jâ:; 't terp woaërdache geboore zit, da trèkt ee... - Afleidingen: Melsenaar [Meiëlseneiër]; Melsenas [Meiëlsenâs]; Melses [Meiëlses].

In DO, KA: [Mèlsen]. - Afleidingen: in DO: [Mèlsenèr, Mèlsenas, Mèlses]; in KA: [Mèlsenieiër, Mèlsenas, Mèlses]; in KI: [Mè:Isenjè:ër, Mè:Isenâs, Mè:lses]; in VE: [Meiëlsenjeiër].

mem [mèm]: vrouwenborst. Azoe ne vaveur, die ee nogâl mèmmen.

In DO ook: [mam].

memorie [meemoorie]: geheugen. ' $k$ Weet nie wa ta ta is, moaër min meemoorie is al neich vermindert, da's â:t woaëre zeeker?...

In KI: [memoore].

meneer [menieër]: mijnheer. - Uitdrukkingen: ne groeëte menieër = iemand die het ver geschopt heeft; $n e$ schoeëne menieër $=$ een mooie mijnheer (met pejoratieve bijklank). Afleiding: meneren [menieëren]: iemand met "mijnheer" aanspreken. Ge moet azoeë alt nie menieëren, ge wit toch oe da'k ieët ee, è 'k zi kik oeëk moaër u:t 'n warkmansbroek geschut...

menen [mieënen]: denken, voor waarheid aannemen, voor mening hebben. Ik mieën dache da verkieërt veur èt. -

Uitdrukkingen: da mieënde nie = wat je daar vertelt is toch wel niet waar zeker?; ik mieënet $=\mathrm{ik}$ lach er niet mee, het is ernst; Mieënen is 'n stat, èn die lich vaar van o gat, è ge kunter nie op zitten: repliek op een bewering die werd ingeleid met $i k$ mieën da..., waarmee gezegd wil worden dat men die bewering niet gelooft of bijtreedt. Afleiding: menens [mieënes]: gemeend. Is da mieënes?...

In HA ook: [maanen]. - Afleiding: in HA ook: [maanes].

mengen [mèngen, mingen]: 1 . bemoeien, tussenkomen. - Uitdrukking: Mingd o: doaër nie mee = bemoei je daar niet mee. - 2. synoniem van mengelen [mèngelen, mingelen] (zie aldaar).

mengelen [mèngelen, mingelen]: mengen, onder elkaar doen. Ache zwart è wit mèngelt dè krijchde grijs. Afleiding: mengeling [mèngeling, mingeling]. - Synoniem: mengen [mèngen, mingen].

mengelwerk [mingelwaarek]: vervolgverhaal in dag- of weekblad. In "De Wo:se Klok" stienger in den tijt altit e mingelwaarek, va Konsjâ:ns of azoe-iet, da lâ:zen de meinse geiëren.

Niet in DO, KI, VE, VR.

mennegat [mènnegat]: 1. plaats via dewelke men (desgevallend over ingebuisde sloot) op en af de akker rijdt. Wi zummen ieës wa stieëngru:s op da mènnegat moette kappen, want da's doaër ieëne slijkboel. - 2. synoniem van de akker zelf bij een eventuele telling van het aantal akkers. Witte gei oevvel mènnego:ten da tieëm boe:r wèl eet! - Zie ook: dam [dam] en dam(me)gat [dam(me)gat].

In HA, ME, VE, VR: [minnegat]. Betekenis 2: niet in DO, KI.

mennen [mènnen]: de oogst binnenhalen. 't Is ie:r druk in de poolder no: de boe:re zin on 't mènnen. - Zie ook: oogsten [oesten].

mens [meins]. - Uitdrukkingen: alle meinse groeët $=$ zeer groot; ammoaër

Vernederlandste trefwoorden uit het Het dialect van Beveren (Cools 2000: 316) 
den' komen tot stand op basis van de synchrone correspondentieregels die tussen het dialectische fonologische systeem en dat van de Nederlandse standaardtaal bestaan. Het is hier echter niet de plaats om uitvoering uit te weiden over vernederlandsingen (en de problemen daarbij); ik verwijs hiervoor naar Van Keymeulen 1992 en 2004 en naar Rys en Van Keymeulen 2009. In wat volgt, wil ik vooral wijzen op een opmerkelijke, typisch 'volkslinguïstische' tendens, die zo sterk is dat het impliciete of expliciete doel van het lokale woordenboek zelfs voorbijgeschoten wordt.

Zeer veel amateurs stellen er namelijk prijs op dialectische trefwoorden te vormen in een zelfgemaakte dialectspelling. Het trefwoord ziet er dan erg 'authentiek' uit; de uitspraak van het woord wordt in de vorm van het trefwoord zelf aangegeven. Een spelling ontwerpen voor een dialect is echter niet makkelijk; het vergt inzicht in de fonologische structuur ervan - een inzicht dat bij veel amateurs door gebrek aan scholing afwezig is. Een en ander loopt dan ook soms verkeerd af. Voor Brabantse of Vlaamse dialecten kan een amateur zich nog min of meer uit de slag trekken; de Limburgse toondialecten bijv., met soms meer dan 40 verschillende klinkerfonemen, kunnen echter voor zeer veel problemen zorgen. Er zijn ten behoeve van dialectliefhebbers dan ook richtlijnen geschreven over hoe men een dialectspelling tot een goed einde kan brengen; de bekendste voor de zuidelijke dialecten is waarschijnlijk de Referentiespelling voor alle Brabantse dialecten (1999) (zie echter ook Cajot 1995 en Van Keymeulen 2003).

Hoewel de bestaande richtlijnen hopelijk een gunstig effect hebben gehad op de kwaliteit van de dialectspellingen, valt het op dat veel auteurs toch een of andere persoonlijk toets willen geven aan de spelling. Ze kennen de bestaande richtlijnen wel, maar wensen er toch aan te sleutelen. Die neiging vloeit m.i. vooral voort uit de behoefte zich het dialect a.h.w. 'toe te eigenen' via het ontwerpen van de spelling ervoor. Het schrijven van een woordenboek wordt blijkbaar ook voor een dialect aangevoeld als een codificerende activiteit - een aantal auteurs drukt overigens de wens uit dat de spelling ook zal kunnen dienen bij het schrijven van dialectliteratuur.

Opmerkelijk is dat heel wat amateurs er niet bij stilstaan dat een dialectisch trefwoord in een zelf ontworpen dialectspelling impliceert dat men het dialect goed moet kennen en kunnen uitspreken, voor men een woord kan opzoeken - aangenomen dat de gebruiker de moeite genomen heeft om de uitleg omtrent de soms complexe spelling in de inleiding op het woordenboek te lezen en te memoriseren. Veel auteurs schrijven dus een woordenboek voor degenen die er het minste behoefte aan hebben, nl. de goede dialectsprekers, die uit de aard der zaak zowel het woord als de uitspraak ervan nog beheersen. De dialectwoordenschat is dan wel 'voor het nageslacht' bewaard, maar is helaas niet voor dat nageslacht ontsloten. Daarnaast zijn er ook nog andere nadelen aan de werkwijze verbonden: niet alleen worden de gebruikers geconfronteerd met zeer ongewone schriftbeelden, zeker als er veel diakritische tekens gebruikt worden, maar ook is de alfabetische volgorde van de trefwoor- 
den niet steeds evident. Een woord opzoeken is in sommige plaatselijke woordenboeken m.i. ook voor de dialectspreker zelf geen eenvoudig karwei.

Een minderheid van amateurwoordenboeken vernederlandst de dialectwoorden. Daardoor zijn de trefwoorden toegankelijk voor een grotere groep gebruikers (bijv. die van de veronderstelde dialectloze toekomst) doordat ze beter aansluiten bij de schriftbeelden die men gewend is uit de standaardtaal. Informatie over de uitspraak kan overigens gemakkelijk in de microstructuur toegevoegd worden, bijv. in IPA-schrift, al zullen amateurs ook dan geneigd zijn terug te grijpen naar zelfgemaakte spellingen. De procedure veronderstelt echter inzicht in de klankstructuur van het dialecten en inzicht in de etymologie van het betreffende dialectwoord, iets wat wel eens boven de kracht gaat van ongeschoolde lexicografen. De intuïtieve correspondentieregels die hierboven werden geponeerd, zorgen er echter wel voor dat de weinige plaatselijke woordenboeken die de dialectwoorden als vernederlandste trefwoorden presenteren het er toch vrij goed vanaf brengen. Een mooi voorbeeld is Cools (2000), die zich tot vernederlandsingen verplicht zag, aangezien zijn woordenboek een (klein) gebied bestrijkt, waar toch heel wat fonologische differentiatie voorkomt.

De meeste woordenboeken gebruiken dus dialectwoorden als trefwoorden, in al dan niet vernederlandste vorm. Het is markant dat veel auteurs niet inzien dat op die manier het dialect voor de toekomst niet ontsloten wordt. Men moet in beide gevallen het dialect immers kennen om een woord op te zoeken. De handleiding van Van Keymeulen (2003) probeert de aandacht op die tegenstrijdigheid te vestigen en roept op om het woordenboek via een AN $\rightarrow$ dialectregister om te draaien, ${ }^{15}$ zodat het woordenboek ook een antwoord geeft op de vraag 'Hoe zeg ik $x$ in het dialect'. Ook in het geval van dialectwoordenboeken is een grondige reflectie over de noden van de gebruiker een noodzakelijke voorwaarde om tot een goed woordenboek te komen.

\section{Het belang van de amateurlexicografie voor de wetenschap}

De plaatselijke dialectwoordenboeken vormen een bont gezelschap. De overgrote meerderheid ervan is geschreven door taalkundig ongeschoolde lexicografen. Er zijn echter ook woordenboeken van hoge kwaliteit, die bewijzen dat de lexicografie binnen het bereik ligt van verstandige dialectliefhebbers, die zich willen laten voorlichten (o.a. door de richtlijnen van de Referentiespelling (1999), Cajot (1995) of Van Keymeulen (2003)), die de grenzen van hun kunnen inzien en die zich laten leiden door het voorbeeld van een bestaand goed woordenboek. Sommige woordenboeken zijn de vrucht van tientallen jaren werk en dwingen door hun omvang respect af voor de werkkracht van de lexicograaf. In wat volgt, probeer ik aan te geven wat het wetenschappelijke belang kan zijn van die 177 woordenboeken. Eerst heb ik het over de opzet (\$ 3.1) en de beperkingen $(\S 3.2)$ van de drie grote regionale dialectwoordenboeken van het zuidelijke Nederlands; daarna doe ik een voorstel om de gegevens in de amateurlexicografie te ontsluiten (§ 4). 


\subsection{De drie grote regionale woordenboeken (GRW) van het zuidelijke Nederlands}

De opzet van de drie grote dialectwoordenboeken van het zuidelijke Nederlands was reeds het onderwerp van een artikel door Kruijsen en Van Keymeulen in Lexikos (1997). We vatten zeer kort samen. In 1960 nam prof. A. Weijnen aan de Nijmeegse universiteit het initiatief om de dialectwoordenschat te verzamelen van het Brabantse en Limburgse dialectgebied, d.i. resp. de dialectwoordenschat van de provincies Noord-Brabant (Nederland), Antwerpen en Vlaams-Brabant (allebei België), en de provincies Nederlands en Belgisch Limburg. Het Woordenboek van de Brabantse Dialecten (WBD) werd in 2005 afgerond; het Woordenboek van de Limburgse Dialecten (WLD) in 2008. In 1972 volgde prof. W. Pée aan de Universiteit Gent Weijnens voorbeeld met het Woordenboek van de Vlaamse Dialecten (WVD) voor Frans-, West-, Oost- en Zeeuws-Vlaanderen. De drie woordenboeken bestrijken drie geografisch complementaire gebieden en zijn alle drie volgens hetzelfde principe opgezet.

Weijnen koos voor een onomasiologische ordening. ${ }^{16}$ De 3 GRW zijn dus thematisch opgezet: binnen drie delen (I. Landbouwwoordenschat, II. Vakwoordenschat en III. Algemene Woordenschat) worden afleveringen gepubliceerd die telkens aan een bepaald onderwerp zijn gewijd: bijvoorbeeld 'Landerijen en Behuizing', 'Het paard', 'Flora' ... Elke aflevering bestaat uit een reeks woordenboekartikelen die alle dezelfde structuur hebben (zie de voorbeeldbladzijde hierna): na een titel in de standaardtaal volgt een omschrijving van het behandelde begrip (+ eventueel nog andere toelichtingen), de bronnenlijst en dan de reeks vernederlandste trefwoorden (met vanaf deel III eventueel nog lexicale varianten), gevolgd door aanduidingen omtrent frequentie en geografisch bereik van het woord. Het WVD heeft van bij het begin elke aflevering in twee parallelle publicaties uitgebracht: een woordenboektekst voor het 'grote publiek' en een parallel 'Wetenschappelijk Apparaat' (met dezelfde informatie, maar dan meer gedetailleerd en in code) voor de wetenschapper (voor meer details: zie Kruijsen en Van Keymeulen 1997). De drie woordenboeken zijn alle gebaseerd op (schriftelijk) materiaal dat door de redactie zelf verzameld is (het zgn. 'eigen materiaal') en op gegevens uit oudere vragenlijsten en gepubliceerd materiaal (het zgn. 'vreemde materiaal').

Zowel WBD/WLD als WVD putten ook gegevens uit de plaatselijke amateurwoordenboeken; het WVD beperkt zich daarbij van bij het begin tot vier regionale dialectwoordenboeken (nl. De Bo, Joos, Teirlinck en vanaf WVD I,4 ook het WZD) en twee grote stadswoordenboeken (Desnerck voor Oostende en Lievevrouw-Coopman voor Gent). Het WBD en WLD maken meer gebruik van de amateurlexicografie; vanaf deel III hebben de redacties een lijst van zgn. 'canonieke' (d.i. 'goedgekeurde') lokale woordenboeken opgesteld, waaruit gegevens gehaald werden wanneer het andere materiaal wat zwak uitviel (zie de inleidingen op deel III). De informatie van de plaatselijke (of regionale) woordenboeken wordt door de 3 GRW zeer onvolledig verwerkt. Lang niet alle 


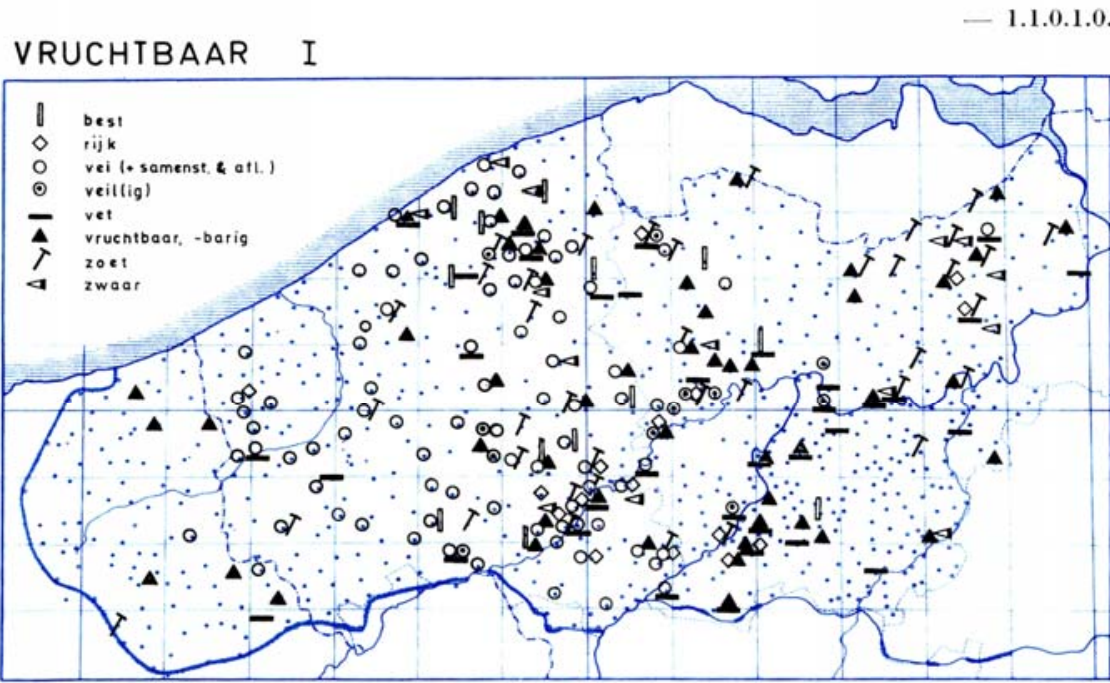

\section{VRUCHTBAAR}

[Fertile, productif - fertile, productive - fruchtbar, ertragreich.]

Goed geschikt om gewassen te telen, een goede opbrengst gevend.

WVD 1,$23 ; 4,24-25-55$.

I. VRUCHTBAAR (Kaart).

best: het type BEST(E) LAND, GROND, - PARTIJ e.d. s p o r. WV oost en $\mathrm{OV}$ west.

dragend : s p o r. Meetjesl dròònt, ook Lede goet dròògant.

eerst : Noordpene eeasta lant.

fel: s por. FV, ook Eeklo.

fertil : Ebblingem firtiel.

goed : het type GOED LAND, GOEDE GROND, GOED STUK e.d. a l g. WV, OV;

frekw. FV (zfd).

groeizaam : Destelbergen (zfd).

jeugdig: z e l d z. WV oost, ook St.-

Martens-Lierde.

kweekzaam : Gent (zfd).

mals : Mater.

open : St.-Pieters-op-den-Dijk.

rijk : frekw. omg. Kortrijk riekə, rika; z eldz. OV raek, rek, reik; ook Wulveringem, Vinkem. vei : a lg. WV; z eldz. FV vei, Meetjesl en omg. Nevele vaej.

Wdb : DB.

veiachtig : Ruiselede.

veiig : $\mathrm{zeldz}$. WV veiiech, veiəch, veigว, ook St.-Gillis.Waas vaejga gront.

veil : s p o r. WV oost en $O V$ west veil, vaejl.

Wdb : Loq : St.-Martens-Leerne.

veilig : Melle, Eine (zfd). veischot: Zedelgem, Ieper veischot.

veischotig : Snaaskerke veischootach.

veischottig : zeld z. WV veischo. təch, veischotiech, ook Vinkt vaejschotəch. veizaam : Oostkamp veizò̀m.

Wdb : DB.

veizamig : Oostkamp veizòòməch.

vet : frekw. OV; s por. WV; ook

Meteren.

vettig : Melle, Lede.

vruchtbaar : frekw. OV en WV oost; s p o r. FV vrugbò̀r.

vruchtbarig : s p o r. FV vrugbòòrach, vrugbò̀riech; ook Sinaai, Meldert vrugbòòrach.

weeldig : Alveringem, Poperinge wil. diech.

zoet: s por. WV, OV; ook Ebblin. gem zoet, zoest.

Een voorbeeldbladzijde van de 'woordenboektekst' uit WVD I,1: 1717 
woorden werden geëxcerpeerd en de redactie beperkte zich doorgaans in voorkomend geval tot de mededeling van de attestatie van de woordvorm (soms met een korte semantische toelichting). ${ }^{18}$

\subsection{Beperkingen op lexicaal en semantisch gebied van de 3 GRW}

De onomasiologische aanpak van Weijnen, waarbij hij uitging van 'begrippen' en daarbij dan per begrip de dialectwoorden vermeldde die bij het refereren aan dat begrip gebruikt konden worden, is erg vruchtbaar gebleken op geografisch gebied. Aangezien alle dialectwoorden voor één begrip netjes bij elkaar worden gepresenteerd, ligt het materiaal klaar om een taalkaart te tekenen. Op semantisch vlak echter heeft de onomasiologische ordening belangrijke beperkingen veroorzaakt. In de jaren '60 van de vorige eeuw hebben Weijnen en De Tollenaere, hoofdredacteur van het WNT, een boeiende wetenschappelijke discussie gevoerd omtrent de vraag of het mogelijk is 'betekenis' weer te geven in een onomasiologisch georganiseerd woordenboek (zie Weijnen 1961, 1963, 1967, De Tollenaere 1960, 1968). Volgens De Tollenaere is dat enkel mogelijk in een semasiologisch woordenboek, waarbij men uitgaat van het woord zelf, en daarvan in de microstructuur de betekenis(sen) beschrijft. In onomasiologisch ingerichte woordenboeken als WBD/WLD/WVD kunnen enkel gebruikswijzen van de woorden meegedeeld worden, geen betekenissen. De Tollenaere (1968: 199 vlg.) zegt hierover: "De ideologische lexikografie kan dus principieel geen bemoeienis hebben met wat men betekenis noemt. Haar beoefenaars zijn in dit opzicht te benijden".

De uitslag van de discussie was dat Weijnen zich bij de visie van De Tollenaere aansloot. In de 3 GRW kan noch de titel van een woordenboekartikel (in ons voorbeeld VRUCHTBAAR), noch de semantisch-encyclopedische omschrijving die daarop volgt (in ons voorbeeld 'Goed geschikt om gewassen te telen ...'), in principe als een betekenisomschrijving voor alle daarop volgende dialectwoorden beschouwd worden. Titel en omschrijving duiden enkel op een begrip waaraan door de daarna opgelijste woorden gerefereerd kan worden; die woorden kunnen echter een ruimer toepassingsbereik hebben (niet een enger!) dan dat dat door de titel of omschrijving wordt aangegeven. Dat is in ons voorbeeld voor zeer veel woorden het geval: het is duidelijk dat o.a. best, goed, rijk en vet een ruimer toepassingsbereik hebben dan enkel maar 'vruchtbaar'. Pas wanneer het woordenboek af is, en men via de alfabetische registers kan opzoeken in welke woordenboekartikelen een bepaald woord voorkomt, kan men een beter zicht krijgen op de betekenisinhoud van dat woord. Kortom, hoewel de 3 GRW het woord 'woordenboek' in hun titel dragen, zijn het vooral onomasiologisch geordende materiaalverzamelingen die als bouwstoffen voor een woordenboek kunnen dienen.

De 3 GRW zijn door de ordening van de macrostructuur dus in de eerste plaats woordatlassen; ze geven in principe geen betekenissen weer. Ze zijn op te vatten als thematisch geordende thesauri van gebruikswijzen van dialect- 
woorden in de zuidelijke dialecten van het Nederlands. Die geografische focus, samen met de onomasiologische opvraagtechniek, heeft in de praktijk ook meegebracht dat de klemtoon ligt op de woorden voor concreta; woorden met abstracte betekenis zijn zowel moeilijk op te vragen als moeilijk in onomasiologische woordenboekartikelen in te delen. ${ }^{19}$ De 3 GRW zijn dan ook vooral rijk aan substantieven en werkwoorden, in mindere mate aan adjectieven. Woorden van de gesloten woordklassen ontbreken nagenoeg volledig.

\subsection{De bijdrage van de amateurlexicografie}

Uit het bovenstaande is ongetwijfeld duidelijk geworden dat de 3 GRW de dialectwoordenschat van de zuidelijk-Nederlandse dialecten niet 'in zijn volheid' inventariseren. Niet alleen is er een semasiologische benaderingswijze nodig om de betekenis van woorden weer te kunnen geven, maar ook is de microstructuur in de 3 GRW relatief arm an informatie. Behalve de begripsomschrijving, krijgen we op werkelijk systematische wijze enkel trefwoorden en de lokalisatie daarvan. Het is ook de bedoeling (geweest) om van elk dialectwoord de uitspraak weer te geven. De behandeling van de fonetische component verschilt tussen WBD/WLD en WVD; WVD heeft overigens voor deel III zeer sterk op de fonetische component bespaard (voor details hierover: zie Kruijsen en Van Keymeulen 1997). De microstructuur bevat geen morfologische of syntactische informatie. De 3 GRW zijn ook zeer arm aan collocaties - er zijn bijv. geen voorbeeldzinnen; spreekwoorden of uitdrukkingen worden overigens niet systematisch opgevraagd.

Gelukkig zijn er dus de amateurwoordenboeken, die nagenoeg alle semasiologisch geordend zijn en waarvan er zeer veel een heel wat uitgebreidere microstructuur hebben dan de 3 GRW. Hoewel de kwaliteit van de amateurwoordenboeken heel sterk kan variëren, leveren ze toch een schat aan additionele gegevens bij de 3 GRW. Zelfs de kwalitatief mindere woordenboeken kunnen aan de wetenschap nuttige informatie leveren omtrent het voorkomen van een bepaald woord, met tenminste een aanduiding omtrent de betekenis ervan. Zaak is dat de gevestigde lexicografie de amateurs ondersteunt en begeleidt. Die begeleiding heeft twee aspecten: lexicografische basisnoties bij de amateurs aanbrengen en hen hun wetenschappelijke beperkingen (op het vlak van fonetica en historische taalkunde) leren aanvaarden.

\section{Naar een Woordenboek van de Nederlandse Dialecten (WND)}

Een digitaal doorzoekbare database die de gegevens van alle amateurwoordenboeken zou bevatten, zou dus een zeer welkome aanvulling zijn bij de gegevens van de 3 GRW. Voor het zuidelijke Nederlands is er nu een bibliografie voorhanden (Van Keymeulen e.a. 2007); ik betwijfel of er een bibliotheek is waar de hele verzameling bijeenstaat. Heel wat van de plaatselijke woordenboeken zijn immers in eigen beheer en maar in beperkte oplage uitgegeven - 
ze zijn daardoor soms moeilijk op te sporen of te verwerven. Het inscannen en verder bewerken van de papieren teksten vormt technologisch geen onoverkomelijke problemen - eventueel zijn er wel auteursrechtelijke hindernissen te overwinnen. ${ }^{20}$

Een database met daarin alle artikelen van de verschillende regionale en lokale dialectwoordenboeken als aparte bestanden zou wel in elk geval verrijkt moeten worden met vernederlandste trefwoorden (het liefst met aanduiding van de morfologische geleding en van de woordsoort) om een efficiënt gebruik mogelijk te maken - een werk dat noodzakelijkerwijs manueel zal moeten gebeuren. Ideaal zou zijn de bestanden ook via de Nederlandse standaardtaal toegankelijk te maken door het vernederlandste dialectwoord ook naar het Algemeen Nederlands te vertalen en/of het te voorzien van een thematische markering - in beide gevallen uiteraard op grond van een goed overdacht en eenvormig systeem. ${ }^{21}$

Voorbeeld uit: Pieters 1995: 319 (Woordenboek van het Lokers dialect):

Oorspronkelijk woordenboekartikel:

slaupersmisse: de zondagse elfuurmis, vroeger de laatste misviering op zondag. De slaupersmisse dè wār veur de dee die dèn nie vroeg uit (h)odder bēde kosten. Zie ook rijkemēnsemisse.

Manueel toe te voegen verrijkingen:

$$
\begin{aligned}
& \text { slaper-s-mis (= vernederlandsing, met morfologische indeling) } \\
& \text { zelfstandig naamwoord (= woordsoort) } \\
& \text { elfuurmis (= vertaling in het Algemeen Nederlands) } \\
& \text { religie (= thematische aanduiding / semantisch veld) }
\end{aligned}
$$

Het spreekt vanzelf dat er nog andere verrijkingen aangebracht kunnen worden, en ook kan de database verder verfijnd worden, naargelang van de aard van de microstructuur van de onderscheiden woordenboeken. De meest essentiële verrijking is wel de vernederlandsing van de dialectische trefwoorden indien dat niet gebeurt, is de database ontoegankelijk en dus zinloos.

\section{Conclusie}

De geschiedenis van de Nederlandse (en Afrikaanse!) woordenschat kan maar geschreven worden wanneer we de beschikking hebben over inventarissen van drie soorten woordenschat: de woordenschat van de hedendaagse standaardtaal, de historische woordenschat en de uitsluitend oraal overgeleverde woordenschat. De inventarissen van de twee eerste soorten woordenschat worden vooral (en voor de historische periode uitsluitend) op schriftelijke bronnen gebaseerd. De registratie van de louter oraal overgeleverde woordenschat, de 
woordenschat dus van de traditionele dialecten, is een dringende taak, wegens het verdwijnen (sedert de jaren '60 van de vorige eeuw) ervan onder de druk van de veranderende maatschappij en door de introductie van het AN in brede lagen van de bevolking.

De optekening van het lexicon van de dialecten is een gigantische taak, niet alleen wegens de uitgebreidheid en geografische differentiatie ervan zowel op formeel als semantisch gebied - maar ook wegens de moeizame verzamelmethode. Alle gegevens moeten immers bij de oudste generatie dialectsprekers geëliciteerd worden, meestal via mondelinge of schriftelijke enquête. Hoewel de $3 \mathrm{GRW}$ in termen van menskracht en financiën zeer grote ondernemingen zijn, hebben ze toch zeer veel moeten laten liggen - mede doordat de opzet van de woordenboeken veeleer taalgeografisch dan semantisch gericht was.

Gelukkig is er nu de dialectrenaissance. Om de registratie van de verdwijnende/reeds verdwenen Nederlandse dialectwoordenschat tot een goed einde te brengen, is het nodig dat de professionele dialectlexicografie een verbond sluit met de amateurlexicografie. De begeleiding van amateurlexicografen is m.i. niet enkel een vrijblijvende dienstverlening, maar is ook een zaak van wetenschappelijk belang. Het zijn de amateurs die de tijd en de motivatie hebben om plaatselijk een diepgaandere inventarisatie te verrichten dan een professionele dialectlexicograaf, die een heel gebied moet overzien, ooit zal kunnen doen. Zaak is om alle gegevens die door de amateurlexicografie zijn verzameld, in een efficiënt doorzoekbare database, een Woordenboek van de Nederlandse Dialecten (WND), onder te brengen.

\section{Eindnoten}

1. Het typoscript voor dit artikel werd afgesloten eind 2007.

2. Zie onder andere Niedzielski en Preston $(2000,2003)$ en recenter werk als Preston (2005) en Preston en Niedzielski (2008).

3. België heeft drie officiële talen: Nederlands (voor de Vlamingen), Frans (voor de Walen), Duits (in de zgn. Oostkantons). Brussel is officieel tweetalig; 85 à 90\% van de bevolking bekent zich echter tot de Franstalige cultuur (we maken abstractie van de talrijke immigranten met Europese of niet-Europese thuistalen). De numerieke verhoudingen zijn (afgerond): Vlaanderen 6000 000; Wallonie: 3400000 (met inclusief de 75000 Duitstaligen), Brussel 1000000 .

4. Met de term zuidelijk-Nederlands proberen we het woord Zuid-Nederlands te vermijden. Zuid-Nederland is immers een lastige geografische aanduiding. Men kan er Nederlandstalig België mee bedoelen, het zuiden van Nederland of die twee gebieden samen.

5. Het valt op dat er nagenoeg geen vrouwelijke amateurlexicografen zijn. Mevr. Ghijsen was de uitzondering die de regel bevestigde.

6. In 1994 werd het WZD gedigitaliseerd o.l.v. Rinus Willemsen; in 1997 werd begonnen met het inlezen van de voorbeeldzinnen door een honderdtal dialectsprekers. Het WZD is met de 
publicatie van de CD-rom in 1998 waarschijnlijk het eerste 'sprekende' dialectwoordenboek ter wereld.

7. Het Fries heeft in Nederland een erkenning op een 'hoger' niveau, nl. op basis van deel I van het Handvest.

8. Het kaartje is genomen uit Van Keymeulen e.a. 2007 en is van de hand van Ronny Keulen (met dank aan Valerie Bouckaert voor het overtekenen en aanvullen ervan). De twee sterretjes in het zuidoosten ten zuiden van de taalgrens staan voor Gemmenich en Eupen, twee Duitstalige gemeenten in de Belgische provincie Luik. Het kaartje laat geen aantallen zien, maar geeft aan of er voor een bepaalde plaats tenminste één woordenboek is.

9. Het dialect van de nu grotendeels verdwenen volkswijk 'Marollen', Marols of Marollien genoemd, zou het 'échte' Brussels geweest zijn.

10. Strikt genomen zou men bij een vergelijking ook het inwonersaantal/aantal gemeenten van de provinies moeten verrekenen; maar de verhoudingen springen ook nu al in het oog.

11. ABN staat voor Algemeen Beschaafd Nederlands. Het is tekenend voor de verandering in de tijdgeest dat men het woord Beschaafd tegenwoordig weglaat; de standaardtaal heet nu Algemeen Nederlands (AN). Men vond achteraf namelijk - overigens terecht - dat men ook in het dialect 'beschaafd' kan zijn.

12. De technische term voor een contrastief dialectwoordenboek is idioticon (afgeleid van het Griekse idios 'eigen'). Het woord wordt tegenwoordig nauwelijks nog gebruikt wegens de associatie met het woord idioot. Een zeldzame uitzondering is het woordenboek voor Tienen en Hoegaarden van Kempeneers (2004).

13. Een zeldzame uitzondering hierop is het woordenboek van het Hasselts van Staelens (1982), waar het AN-woord voorop gaat en in het Hasseltse dialect vertaald wordt, gevolgd door een betekenisomschrijving in het AN.

14. In woordenboeken die een relatief groot geografisch gebied bewerken, is het moeilijk om recht te doen aan de fonogeografische differentiatie. De 19de-eeuwse regionale dialectwoordenboeken geven de uitspraakvariatie niet weer (eerste verdienstelijke poging is Tuerlinckx 1886).

15. We gaan hier niet in op de problemen die dat omdraaien kunnen meebrengen. Voor zeer veel dialectwoorden is er meer dan één AN-vertaling mogelijk, waartussen het lastig kiezen is.

16. Weijnen liet zich daarbij wellicht inspireren door de beschrijvingen van het volksleven in een aantal dorpen in de drooggelegde Zuidzeepolders, waarbij de opgetekende woordenschat in een systematische opzet werd opgenomen (zie Goossens en Van Keymeulen 2006: 78).

17. De vertalingen van de titel in Frans, Engels en Duits werden vanaf WVD I,2 weggelaten.

18. Ik ga hier niet in op de verschillen tussen het WBD/WLD en het WVD in de redactionele behandeling van de gegevens uit bestaande woordenboeken.

19. De afleveringen bij het WVD over de karaktertrekken en de gevoelens (WVD III, 4 en 5) leggen getuigenis af van de worsteling van de redacteurs met onomasiologische indelingen van abstract-emotionele begripsvelden.

20. Enkele proeven met de 19de-eeuwse woordenboeken hebben wel laten zien dat scannen en automatisch in een tekstbestand omzetten geen eenvoudige klus zal worden wegens de slechte drukkwaliteit van de oudere werken.

21. Ik ga hier niet in op de problematiek m.b.t. het vertalen van de dialectwoorden in het $\mathrm{AN}$ of het onderbrengen van de betekenissen in thematische betekenisvelden. De concrete uitwerking van een en ander is overigens ongetwijfeld erg complex. 


\section{Referenties}

Cajot, J. 1995. Hoe maak ik een dialectwoordenboek. Een handleiding voor Limburgers en anderen die dialectwoorden willen spellen, verzamelen en beschrijven. Mededelingen van de Vereniging voor Limburgse Dialect- en Naamkunde nr. 78/79. Hasselt: Vereniging voor Limburgse Dialecten Naamkunde.

Cools, H. 2000. Het Dialect van Beveren en zijn deelgemeenten. Met toelichtingen over afwijkingen in Doel, Haasdonk, Kallo, Kieldrecht, Melsele, Verrebroek en Vrasene door Abdon Van Bogaert. Beveren: Gemeentebestuur.

Cornelissen, P.J. en J.B. Vervliet. 1899-1903. Idioticon van het Antwerpsch dialect (stad Antwerpen en Antwerpsche Kempen). Gent: Siffer. Aanhangsel (1906). Gent: Siffer. Bijvoegsel (1936-1938). Turnhout: Koninklijke Vlaamsche Academie voor Taal- en Letterkunde.

De Belie, A. 2006. Woordenboek van het Belseels dialect. Belsele: Culturele Kring Baudelo.

De Bo, L. 1873. Westvlaamsch idioticon. Brugge: Gailliard. Heruitgave door Joseph Samyn. 18901892. Gent: Siffer. Herdruk 1970, 1976, 1984. Handzame: Familia et Patria.

Debrabandere, F. 1999. Kortrijks Woordenboek. Kortrijk/Brugge: De Leiegouw/Van de Wiele.

Depraetere, E. e.a. 2007. Aé's ge dat lui'ë leest teus hoörde hoe da'me wilder klapp'n al de kant'n van Anzegêm. Klanken, woorden en zegswijzen uit de streek van Anzegem, Kruishoutem, Oudenaarde, Waregem (Potegem), Wortegem-Petegem, Zingem, Zwevegem (Moen, Heestert, Otegem), en verder tot in ... Deerlijk, Zulte, Aarsele, Ruiselede ... Anzegem: Davidsfonds.

Desnerck, R. 2006. Oostends woordenboek. De Haan: Roland Desnerck.

De Tollenaere, F. 1960. Alfabetische of ideologische lexicografie? Bijdragen tot de Nederlandse Taal- en Letterkunde. Uitgegeven vanwege de Maatschappij der Nederlandse Letterkunde I. Leiden: E.J. Brill.

De Tollenaere, F. 1968. Problemen van het dialectwoordenboek. Theorie en praktijk. Tijdschrift voor Nederlandse Taal- en Letterkunde 84: 197-212.

Devos, M. 1973. De Bo en het Noordwestvlaams. Album Willem Pée: 131-140. Tongeren: Michiels.

Ghijsen, H.C.M. 1964. Woordenboek der Zeeuwse Dialecten. Den Haag: Van Goor. [Fraanje, K. e.a.. 2003. Supplement Woordenboek der Zeeuwse Dialecten. Krabbendijke: Van Velzen]

Goossens, J. en J. Van Keymeulen. 2006. De geschiedenis van de Nederlandse dialectstudie. Handelingen van de Koninklijke Commissie voor Toponymie en Dialectologie 78: 37-97.

Hoeufft, J.H. 1836. Proeve van Bredaasch taal-eigen of Lijst van eenige in de stad en den lande van Breda gebruikelijke en in sommige oorden van ons vaderland min gewone woorden en spreekwijzen, verzameld en toegelicht. Breda: Sterk.

Joos, A. 1900. Waasch idioticon. Gent/St.-Niklaas: Siffer/Strijbol. Herdruk 1979. St.-Niklaas: Danthe.

Kempeneers, P. 2004. Tiens en Hoegaards idioticon. Tienen: Drukkerij Peeters.

Kooijman, G. 1985. Thematisch Woordenboek van het Tungelroys. Amsterdam: Rodopi.

Kruijsen, J. en J. Van Keymeulen. 1997. The Southern Dutch Dialect Dictionaries. Lexikos 7: 207228.

Lievevrouw-Coopman, L. 1950-1952. Gents woordenboek. Koninklijke Vlaamse Academie voor Taalen Letterkunde Reeks VI, nr. 68. Gent: Erasmus. Herdruk 1974. Gent: Broers.

Maes, L. 1994. Overmeers Woordenboekje (herzien en uitgebreid). Overmere: Heemkundige Kring.

Moens, B. 1988. Waur is d'n tijd naurtoe? Geillustreerd Waasmunsters Woordenboek. Sint-Niklaas: Ten Bos. 
Moeyaert, C. e.a. 2005. Woordenboek van het Frans-Vlaams. Dictionnaire du flamand de France. Leuven: Davidsfonds.

Niedzielski, N.A. en D.R. Preston. 2000. Folk Linguistics. Berlijn: Mouton de Gruyter. [Een herziene paperbackversie verscheen in 2003.]

Pletinckx, L. 2003. Woordenboek van het Asses. Bijdrage tot de studie van de West-Brabantse streektaal. Asse: Koninklijke Heemkring Ascania.

Pieters, M. 1995. Woordenboek van het Lokers Dialect. Lokeren: Oelbrandt.

Preston, D.R. 2005. What is Folk Linguistics? Why Should You Care? Lingua Posnaniensis. Review of General and Comparative Linguistics 47: 143-162.

Preston, D.R. en N.A. Niedzielski. 2008. Trends in Folk Linguistics. Achard-Bayle, G. en M.A. Paveau. Pratiques. La linguistique populaire ou la valeur des savoirs profanes. (december 2008.)

Referentiespelling (1999) = Hoe schrijf ik mijn dialect. Referentiespelling voor alle Brabantse dialecten. Uitgegeven door de Stichting Brabantse Dialecten (Vlaanderen) en het Noord-Brabants Genootschap (Nederland). Leuven: Acco.

Rutten, A. 1890. Bijdrage tot een Haspengouwsch Idioticon. Antwerpen: Zuidnederlandsche Maatschappij van Taalkunde, Boucherij. [Met een Bijvoegsel in 1904.]

Rys, K. en J. van Keymeulen. 2009. Intersystemic Correspondence Rules and Headwords in Dutch Dialect Lexicography. International Journal of Lexicography 22: 129-150.

Schuermans, L.W. 1865-1870. Algemeen Vlaamsch Idioticon. Leuven: Van Linthout. Bijvoegsel aan het Algemeen Vlaams Idioticon. 1883. Leuven: Fonteyn. Herdruk met inbegrip van het bijvoegsel. 1984. Torhout: Flandria Nostra.

Starck, O. en L. Claessens. 1988, 1995². Dictionnaire Marollien-Français /Français-Marollien. Brussel: Lojipe.

Staelens, X. 1982, 1982², 1989³. Dieksjenèèr van 't (H)essels. Eerste en tweede, verbeterde druk: Hasselt: Heideland. Derde, verbeterde druk: Hasselt: De Langeman.

Teirlinck, I. 1908-1924. Zuid-Oostvlaandersch Idioticon. Gent: Siffer. Herdruk 1986. Handzame: Familia et Patria.

Tuerlinckx, J.F. 1886. Bijdrage tot een Hagelandsch Idioticon. Gent: Zuidnederlandsche Maatschappij van Taalkunde.

Van der Eecken, G. 2007. Woordenboek van het Schellebels Dialect. Met Heemkundige aantekeningen. Schellebelle: Heemkring Schellebelle.

Van Gompel, W. 2002-2006. Reusels Woordenboek. Deel I: De mens; Deel II: De wereld; Deel III: Beroepen en andere bezigheden; Deel IV: Inleiding, schets van het dialect, aanvullingen, registers. Reusel: Heemkunde Werkgroep Reusel.

Van Keymeulen, J. 1992. De Algemene Woordenschat in de grote dialectwoordenboeken (WBD, WLD, WVD). Een methodologische reflectie. Ongepubliceerd proefschrift. Gent: Universiteit Gent.

Van Keymeulen, J. 2003. Dialectwoorden verzamelen. Een praktische handleiding. Handelingen van de Koninklijke Commissie voor Toponymie en Dialectologie 75: 383-506. [Ook als aparte overdruk beschikbaar. Tongeren: Michiels.]

Van Keymeulen, J. 2004. Trefwoorden en lexicale varianten in de grote regionale dialectwoordenboeken van het zuidelijke Nederlands (WBD, WLD, WVD). De Caluwe, J. e.a. (Reds.). 2004. Taeldeman, man van de taal, schatbewaarder van de taal: 897-908. Gent: Academia Press.

Van Keymeulen, J., R. Keulen, J. Swanenberg en T. van de Wijngaard. 2007. Dialectlexicografie in de zuidelijke Nederlanden: bibliografie van de regionale en plaatselijke woordenboeken. Handelingen van de Koninklijke Commissie voor Toponymie en Dialectologie 79: 399-428. 
WBD = Weijnen, A. e.a. 1967-2005. Woordenboek van de Brabantse Dialecten. Assen: Van Gorcum/ Groningen: Gopher.

Weijnen, A. 1961. De semantische en syntactische problematiek van het dialectwoordenboek. Tijdschrift voor Taal-en Letterkunde 78: 81-95.

Weijnen, A. 1963. Het dialectwoordenboek. Woordenboek en Dialect. Bijdragen en Mededelingen der Dialectencommissie van de Koninklijke Nederlandse Akademie van Wetenschappen te Amsterdam 24: 34-52.

Weijnen, A. 1967. De waarde van een dialectwoordenboek. Mededelingen van de Nijmeegse Centrale voor Dialect-en Naamkunde 6: 5-11.

WLD = Weijnen, A., J. Goossens e.a. 1983-. Woordenboek van de Limburgse Dialecten. Assen: Van Gorcum/Groningen: Gopher.

WNT $=$ Woordenboek der Nederlandsche Taal. 1864-1998. Digitale versie 1999. Rotterdam: AND Publishers b.v.

WVD = Devos, M. e.a. 1979-. Woordenboek van de Vlaamse Dialecten. Gent/Tongeren: Michiels.

WVD I, 1 = Devos, M. en H. Ryckeboer. 1979. Woordenboek van de Vlaamse Dialecten. Deel I Landbouwwoordenschat. Afl. 1 'Akkerland en Weiland'. Gent/Tongeren: Michiels. [Met apart uitgegeven Wetenschappelijk Apparaat.]

WVD III, 4 en 5 = De Pauw, T. en M. Devos. 2005 en 2007. Woordenboek van de Vlaamse Dialecten. Algemene Woordenschat. Afl. 4 'Karakter' en Afl. 5 'Verstand en Gevoel'. Gent/Tongeren: Michiels.

WZD = zie Ghijsen, H.C.M. 1964. 